\title{
Can Systemic Anti-CD20 B Cell-Depleting Antibodies Eliminate Meningeal Follicles in Multiple Sclerosis?
}

\author{
Sasha Gupta, MD,* and Scott S. Zamvil, MD, PhD*
}

Neurol Neuroimmunol Neuroinflamm 2021;8:e1000. doi:10.1212/NXI.0000000000001000

\author{
Correspondence \\ Dr. Gupta \\ sasha.gupta@ucsf.edu \\ or Dr. Zamvil \\ zamvil@ucsf.neuroimmunol.org
}

\section{RELATED ARTICLE}

Anti-CD20 Depletes

Meningeal B Cells but

Does Not Halt the

Formation of Meningeal

Ectopic Lymphoid Tissue

Page e1012
Recently, 2 articles have been published in Neurology: Neuroimmunology \& Neuroinflammation addressing these questions. In this issue, Brand et al. ${ }^{8}$ examined whether anti-CD20 $\mathrm{mAb}$ therapy could deplete $B$ cells within mELT in a murine model of MS that develops spontaneous chronic experimental autoimmune encephalomyelitis (EAE) with mELT found around the spinal cord. In this study, the mice were treated with 2 different protocols: (1) prevention (administration from weaning) and (2) treatment after onset of paralysis (clinical score $\geq 3$ ). In both protocols, anti-CD20 mAb therapy did not affect the clinical outcome or demyelination. Anti-CD20 mAb therapy depleted systemic B cells and central B cells within mELT. Although the cellular composition was reduced, mELT remained intact.

In the May 2021 issue, Roodselaar et al. ${ }^{9}$ evaluated the difference between 2 anti-CD20 mAb therapies in a novel murine model of MS. They tested a traditional anti-CD20 mAb therapy (rituximab), which they referred to as "type I" anti-CD20 mAb. In comparison, they tested an Fcengineered $\mathrm{mAb}$ that conferred greater antibody-dependent cellular cytotoxicity ${ }^{10}$ that they referred to as "type II" anti-CD20 mAb. In their model, called delayed type hypersensitivitytertiary lymphoid-like structures (DTH-TLS), mice were immunized with myelin oligodendrocyte glycoprotein (MOG) p35-55 and complete Freund's adjuvant (CFA), which contains Mycobacterium tuberculosis (TB). Twelve days after immunization, heat-killed TB bacteria was injected stereotactically into the piriform cortex. This paradigm resulted in the development of clinically silent mELT that was associated with the presence of microglia followed by activated astrocytes, along with lymphocyte infiltration in mELT. Demyelination was observed within the lateral olfactory tract, adjacent to the site of injection. This model therefore shares histopathologic features of SPMS. Forty days postinduction, mice were treated with either type I or II anti-CD20 $\mathrm{mAb}$ therapy. Both therapies resulted in peripheral $\mathrm{B}$ cell depletion, reduction in $\mathrm{B}$ and $\mathrm{T}$ cells within $\mathrm{mELT}$, and reduced size of $\mathrm{mELT}$. Both were also associated with decreased microglial 
activation. Moreover, type II anti-CD20 mAb reduced astrocyte activation to a greater extent than type I anti-CD20 mAb and was associated with less neuronal death. Of interest, MRI with gadolinium (Gd) after anti-CD20 mAb therapy did not show enhancement, implying a lack of BBB breakdown at the time.

Although both research articles demonstrated depletion of B cells within mELT with systemic anti-CD20 mAb therapy, surprisingly they differed in the preservation of mELT. Differences between these 2 articles may be attributed to the mouse models that were used. Although the DTH TLS model described by Roodselaar et al. recapitulates the histopathology observed in SPMS, it is artificial because it requires direct CNS injury that results in CNS inflammation and mELT formation. In the earlier relapsing phase of MS, there are areas of focal CNS inflammation with $\mathrm{BBB}$ breakdown that corresponds to enhancing lesions on MRI. In SPMS, when the BBB is reestablished, there are fewer or no MRI CNS enhancing lesions. Although Roodselaar et al. demonstrated that there was no MRI enhancement, the MRI was conducted 60 days after anti-CD20 $\mathrm{mAb}$ administration. As the MRI was not performed at the time of anti-CD20 mAb administration, it is unclear whether the anti$\mathrm{CD} 20 \mathrm{mAb}$ penetrated the CNS from residual BBB disruption that resulted from the previous stereotactic injection. It is difficult to the compare results from the DTH-TLS model to the spontaneous EAE model used by Brand et al., which was created by crossing MOG-specific $\mathrm{T}$ cell receptor transgenic mice with MOG-specific B cell receptor knock-in mice. Systemic antiCD20 mAb treatment of spontaneous EAE did not result in clinical benefit or decrease in size of $\mathrm{mELT}$, despite reduction of $B$ cells within mELT. The reduction of meningeal B cells with systemic anti-CD20 mAb therapy is consistent with previous data in spontaneous EAE indicating some degree of anti-CD20 $\mathrm{mAb}$ penetration through an intact BBB. ${ }^{11}$ Overall, data from these 2 research articles do not convincingly support systemic administration of anti-CD20 for treatment of CNS B cells within mELT.

One questions whether other approaches could be used to selectively target CNS B cells in progressive MS. Two phase $1 \mathrm{~b}$ clinical trials that tested intrathecal administration of rituximab for progressive MS showed tolerability, but no clear clinical benefit. ${ }^{5,12}$ Just as Roodselaar et al. tested type II anti$\mathrm{CD} 20 \mathrm{mAb}$, it is possible that CNS targeting with more potent $\mathrm{B}$ cell depleting antibodies may result in greater B cell depletion and improved clinical outcomes. In the future, one can also envisage targeting molecules expressed at the BBB (e.g., selective adhesion molecules) or employing the transferrin receptor 1 to serve as a molecular shuttle to enhance
CNS penetration of $\mathrm{B}$ cell targeting therapies including antiCD20 mAb or Bruton tyrosine kinase inhibitors. Cell-based therapies that target $B$ cells may also have a role in the treatment of progressive MS. In summary, the models used by Roodselaar et al. and Brand et al. recapitulate certain features of SPMS and also highlight the need to use multiple progressive MS models when evaluating CNS B cell targeting approaches.

\section{Study Funding}

The authors report no targeted funding.

\section{Disclosure}

S. Gupta-no disclosures. S.S. Zamvil-Deputy Editor of Neurology: Neuroimmunology \& Neuroinflammation and is a member of the advisory board for the International Society of Neuroimmunology. He has served as a consultant and received honoraria from Biogen-Idec, EMD-Serono, Genzyme, Novartis, Roche/Genentech, and Teva Pharmaceuticals, Inc., and has served or serves on Data Safety Monitoring Boards for Lilly, BioMS, Teva, and Opexa Therapeutics. Currently, S.S. Zamvil receives research grant support from the NIH, the NMSS, The Maisin Foundation, Biogen, and Celgene. Go to Neurology.org/NN for full disclosures.

\section{References}

1. Hauser SL, Waubant E, Arnold DL, et al. B-cell depletion with rituximab in relapsingremitting multiple sclerosis. N Engl J Med. 2008;358:676-688.

2. Molnarfi N, Schulze-Topphoff U, Weber MS, et al. MHC class II-dependent B cell $\mathrm{APC}$ function is required for induction of CNS autoimmunity independent of myelinspecific antibodies. J Exp Med. 2013;210:2921-2937.

3. Weber MS, Prod'homme T, Patarroyo JC, et al. B-cell activation influences T-cell polarization and outcome of anti-CD20 B-cell depletion in central nervous system autoimmunity. Ann Neurol. 2010;68:369-383.

4. Montalban X, Hauser SL, Kappos L, et al. Ocrelizumab versus placebo in primary progressive multiple sclerosis. N Engl J Med. 2017;376:209-220.

5. Bergman J, Burman J, Gilthorpe JD, et al. Intrathecal treatment trial of rituximab in progressive MS: an open-label phase 1b study. Neurology. 2018;91:e1893-e1901.

6. Magliozzi R, Howell O, Vora A, et al. Meningeal B-cell follicles in secondary progressive multiple sclerosis associate with early onset of disease and severe cortical pathology. Brain. 2007;130:1089-1104.

7. Absinta M, Vuolo L, Rao A, et al. Gadolinium-based MRI characterization of leptomeningeal inflammation in multiple sclerosis. Neurology. 2015;85:18-28.

8. Brand R, Zhou Y, Leppert D, et al. Anti-CD20 depletes meningeal B cells but does not halt the formation of meningeal ectopic lymphoid tissue. Neurol Neuroimmunol Neuroinflamm. 2021;8:e1012.

9. Roodselaar J, Zhou Y, Leppert D, et al. Anti-CD20 disrupts meningeal b-cell aggregates in a model of secondary progressive multiple sclerosis. Neurol Neuroimmunol Neuroinflamm. 2021;8:e975.

10. Mössner E, Brünker P, Moser S, et al. Increasing the efficacy of CD20 antibody therapy through the engineering of a new type II anti-CD20 antibody with enhanced direct and immune effector cell-mediated B-cell cytotoxicity. Blood. 2010;115: 4393-4402.

11. Lehmann-Horn K, Kinzel S, Feldmann L, et al. Intrathecal anti-CD20 efficiently depletes meningeal B cells in CNS autoimmunity. Ann Clin Transl Neurol. 2014;1: 490-496.

12. Bhargava $\mathrm{P}$, Wicken $\mathrm{C}$, Smith $\mathrm{MD}$, et al. Trial of intrathecal rituximab in progressive multiple sclerosis patients with evidence of leptomeningeal contrast enhancement. Mult Scler Relat Disord. 2019;30:136-140. 


\title{
Neurology \\ Neuroimmunology \& Neuroinflammation
}

\author{
Can Systemic Anti-CD20 B Cell-Depleting Antibodies Eliminate Meningeal Follicles in \\ Multiple Sclerosis? \\ Sasha Gupta and Scott S. Zamvil \\ Neurol Neuroimmunol Neuroinflamm 2021;8; \\ DOI 10.1212/NXI.0000000000001000
}

This information is current as of May 17, 2021

\begin{tabular}{|c|c|}
\hline $\begin{array}{l}\text { Updated Information \& } \\
\text { Services }\end{array}$ & $\begin{array}{l}\text { including high resolution figures, can be found at: } \\
\text { http://nn.neurology.org/content/8/4/e1000.full.html }\end{array}$ \\
\hline References & $\begin{array}{l}\text { This article cites } 12 \text { articles, } 4 \text { of which you can access for free at: } \\
\text { http://nn.neurology.org/content/8/4/e1000.full.html\#\#ref-list- } 1\end{array}$ \\
\hline Subspecialty Collections & $\begin{array}{l}\text { This article, along with others on similar topics, appears in the } \\
\text { following collection(s): } \\
\text { All Demyelinating disease (CNS) } \\
\text { http://nn.neurology.org//cgi/collection/all_demyelinating_disease_cns } \\
\text { Multiple sclerosis } \\
\text { http://nn.neurology.org//cgi/collection/multiple_sclerosis }\end{array}$ \\
\hline Permissions \& Licensing & $\begin{array}{l}\text { Information about reproducing this article in parts (figures,tables) or in } \\
\text { its entirety can be found online at: } \\
\text { http://nn.neurology.org/misc/about.xhtml\#permissions }\end{array}$ \\
\hline Reprints & $\begin{array}{l}\text { Information about ordering reprints can be found online: } \\
\text { http://nn.neurology.org/misc/addir.xhtml\#reprintsus }\end{array}$ \\
\hline
\end{tabular}

Neurol Neuroimmunol Neuroinflamm is an official journal of the American Academy of Neurology.

Published since April 2014, it is an open-access, online-only, continuous publication journal. Copyright

Copyright $\odot 2021$ The Author(s). Published by Wolters Kluwer Health, Inc. on behalf of the American

Academy of Neurology.. All rights reserved. Online ISSN: 2332-7812.

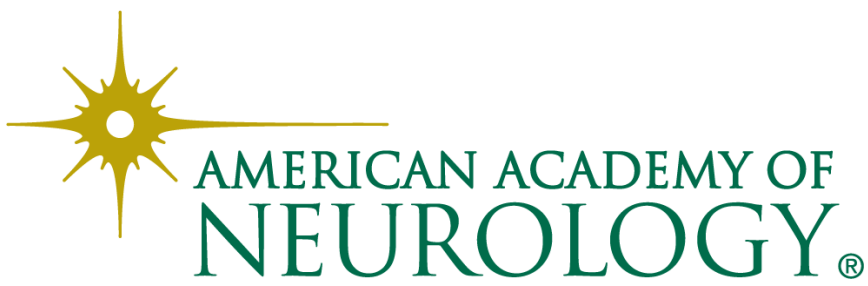

